\title{
IMPLEMENTASI HOT STANDBY ROUTER PROTOCOL (HSRP) PADA PT INDONESIA POWER JAKARTA PUSAT
}

\author{
Anggi Puspitasari ${ }^{1}$, Hairistryan ${ }^{2}$, Raudah Nasution ${ }^{3}$ \\ Program Studi Sistem Informasi, Fakultas Teknologi dan Informatika Universitas Bina Sarana Informatika \\ Jl. Kamal Raya No.18, RT.6/RW.3, Cengkareng Barat., Kecamatan Cengkareng, Kota Jakarta Barat, Daerah \\ Khusus Ibukota Jakarta 11730 \\ ${ }^{2}$ Program Studi Teknik Informatika, STMIK Nusamandiri Jakarta \\ Jl. Kramat Raya No.18, RT.5/RW.7, Kwitang, Kec. Senen, Kota Jakarta Pusat 10450 \\ Email : anggi.aprl@bsi.ac.id ${ }^{1}$, hairistryan@gmail.com ${ }^{2}$, raudah.rhn@ bsi.ac.id $^{3}$
}

\section{Article history}

Received May 09, 2020

Revised May 15, 2019

Accepted May 25, 2019

Available online May

31,2020

Keywords

Networking,

Device Failure,

HSRP
Riwayat

Diterima 09 Mei 2020

Revisi 15 Mei 2020

Disetujui 25 Mei 2020

Terbit 31 Mei 2020

Kata Kunci

Jaringan,

Kegagalan Perangkat, HSRP

\section{ABSTRACT}

The utilization of computer networks is increasingly growing, not only the exchange of data conducted between divisions in one building, but also carried out data exchange between the company or between branches. Data exchange between offices is a very important activity. This activity requires a reliable network system on a company. When the data exchange activity occurs the Router or switch has an important role, namely as the core device of the computer network connecting between different segment. Failure in data exchange may occur if there is a network device failure. At PT Indonesia Power Jakarta Network system failure when the exchange occurs due to malfunction of the WAN Optimizer or router, to improve the SYS team will do maintance with a long time. It can interfere with employee performance and reduce the quality of the computer network, when there is no network switching quickly, precisely and automatically. Therefore, it needs the implementation of Hot Standby Router Protocol (HSRP). With these implementations can improve the quality of the computer network and overcome the failure of the network.

Pemanfaatan jaringan komputer diperusahaan semakin berkembang, tidak hanya pertukaran data yang dilakukan antar divisi didalam satu gedung, tetapi juga dilakukan pertukaran data antar perusahaan atau antar cabang. pertukaran data antar kantor merupakan kegiatan yang sangat penting. Kegiatan ini membutuhkan sistem jaringan yang dapat diandalkan pada sebuah perusahaan. Saat kegiatan pertukaran data terjadi Router atau switch memiliki peranan penting, yaitu sebagai perangkat inti dari jaringan komputer yang menghubungkan antar segment yang berbeda. Kegagalan dalam pertukaran data dapat terjadi apabila ada kegagalan perangkat jaringan. Pada PT Indonesia Power Jakarta kegagalan sistem jaringan saat pertukaran terjadi karena tidak berfungsinya WAN Optimizer atau router, untuk memperbaiki tim SYS akan melakukan maintance dengan waktu yang cukup lama. Hal tersebut dapat mengganggu kinerja karyawan dan mengurangi kualitas jaringan komputer, bila tidak ada peralihan jaringan secara cepat, tepat serta otomatis. Oleh karena itu dibutuhkannya Implementasi Hot Standby Router Protocol (HSRP). Dengan adanya implementasi tersebut dapat meningkatkan kualitas jaringan komputer dan mengatasi kegagalan jaringan tersebut 


\section{PENDAHULUAN}

Meluasnya penggunaan jaringan komputer merupakan motor bagi perkembangan internet yakni cara untuk merangkaikan beberapa komputer sehingga setiap komputer yang ada di dalamnya dapat saling berhubungan dan sebagai sumber daya seperti printer dan perangkat penyimpanan data. Hal ini sangat kontras dengan perkembangan kebutuhan perangkat komputer untuk kehidupan sehari - hari yang semakin tinggi, dalam kegiatan bisnis atau perusahaan, salah satunya yaitu PT Indonesia Power Unit Jasa Pemeliharaan Jakarta yang bergerak dalam jasa pemeliharaan mesin-mesin pembangkit, jasa pengujian alat \& mesin, kalibrasi instrumentasi dan commissioning.

PT Indonesia Power sebagai leading company dalam pembangkitan tenaga listrik di Indonesia merupakan salah satu anak perusahaan PT PLN (Persero) yang memiliki 6 Unit Pembangkit (UP) serta mengoperasikan berbagai jenis pembangkit listrik seperti PLTU, PLTG, PLTGU, PLTA, PLTP dan PLTD yang tersebar di Pulau Jawa, Bali, serta pulau lainnya. Disamping itu PT Indonesia Power juga memiliki Unit Jasa Pemeliharaan (UJH) pembangkit listrik tersebut. UJH telah mengembangkan produk-produk jasa pemeliharaan kebutuhan pelanggan dengan tetap mempertimbangkan aspek lingkungan. Selain itu juga di PT Indonesia Power Unit Jasa Pemeliharaan terdapat jaringan komputer yang salah satu kantornya berada di jakarta, maka jaringan komputer yang ada harus tetap berjalan dan dapat diandalkan untuk berkomunikasi dan bertukar data baik dengan kantor pusat maupun kantor cabang lainnya. Maka dari itu dibutuhkan sistem jaringan Hot Standby Router Protocol (HSRP). Sebuah protocol redundancy standar cisco yang menetapkan sebuah router yang secara otomatis mengambil alih jika router yang lain gagal. Salah satu cara untuk meningkatkan waktu uptime hingga mendekati 100 persen, HSRP dapat digunakan pada jaringan komputer dengan availability yang tinggi dengan menyediakan redundansi IP address network pada hop pertama routing untuk host dan jaringan komputer yang telah dikonfigurasi menggunakan sebuah IP Address default
gateway".(Purwanto,et al, 2018).

Pada kurun waktu satu tahun terjadi beberapa kali kegagalan jaringan yang di sebabkan oleh tidak berfungsinya perangkat WAN Optimizer pada PT Indonesia Power Unit Jasa Pemeliharaan. Kerusakan perangkat jaringan tersebut membuat kinerja karyawan perusahaan menjadi sulit untuk mengakses atau mengirim data. Maksud dari pembuatan Hot Standby Router Protocol (HSRP) pada PT Indonesia Power Jakarta adalah untuk mengatasi masalah yang terjadi apabila mengalami device failure yang mengakibatkan terganggunya lalu lintas pengiriman data.

\section{Jaringan Komputer}

\section{TINJAUAN PUSTAKA}

Jaringan komputer adalah kumpulan dua atau lebih komputer yang saling berhubungan untuk melakukan komunikasi data". Komunikasi data yang biasa dilakukan melalui jaringan komputer dapat berupa data teks, gambar, video dan suara. Dinamakan jaringan komputer (computer networks) jika dalam sekumpulan komputer tersebut dihubungkan media fisik dan software yang memfasilitasi komunikasi antara komputer-komputer tersebut (Yuisar et al. 2015).

\section{Manajemen Jaringan}

Manajemen jaringan adalah sebuah pekerjaan untuk memelihara seluruh sumber jaringan dalam keadaan baik (Khadijah,et al., 2016). The International Organization for Standardization (ISO) mendefinisikan sebuah model konseptual untuk menjelaskan fungsi manajemen jaringan.

a. Manajemen Kesalahan (Fault Management) Menyediakan fasilitas yang memungkinkan administrator jaringan untuk mengetahui kesalahan (fault) pada perangkat yang dikelola, jaringan dan operasi jaringan. Agar dapat segera menentukan apa penyebabnya dan dapat segera mengambil tindakan (perbaikan).

b. Manajemen Konfigurasi (management Configuration) Memonitor informasi konfigurasi jaringan sehingga dampak dari perangkat keras ataupun perangkat lunak tertentu dapat dikelola dengan baik. Hal tersebut dapat dilakukan dengan kemampuan untuk inisialisasi, konfigurasi ulang, pengoprasian dan mematikan perangkat yang dikelola. 
c. Manajemen Performa (Perfomance Management)

Mengukur berbagai aspek dari performa jaringan termasuk pengumpulan dan analisis dari data statistik sistem sehingga dapat dikelola dan dipertahankan pada level tertentu yang dapat diterima.

d. Manajemen Keamanan (Security Management)

Mengatur akses ke sumber daya jaringan sehingga informasi tidak dapat diperoleh tanpa izin. Hal tersebut dilakukan dengan cara:

\section{HSRP}

Menerapkan metode HSRP yang memiliki banyak jalur redundansi. Terdapat satu buah multilayer switch pada core layer dan dua buah multilayer switch yang bekerja pada distribution layer, di mana beberapa port akan berada pada keadaan standby sedangkan port lainnya aktif (Pamungkas, et al.2018).

\section{METODE PENELITIAN}

Metode penelitian yang digunakan

a. Analisa Kebutuhan

Analisa kebutuhan pada jaringan komputer di PT.Indonesia Power Jakarta, sebelum HSRP (Hot Standby Router Protocol) diimplementasikan.

\section{b. Desain}

Desain yang dirancang pada jaringan PT. Indonesia Power Jakarta menyesuaikan dengan topologi dan arsitektur jaringan

c. Implementasi dan Testing

Router akan di konfigurasikan hot standby router protocol (HSRP) yang menghasilkan router active dan menambahkan router standby sedangkan testing client akan saling berkomunikasi dengan client lainnya dengan menggunakan Comand prompt

\section{Ruang lingkup}

Ruang lingkup yang akan dibahas adalah pembatasan saat jaringan berjalan dengan normal sebelum diterapkannya HSRP , saat router mengalami kegagalan sebelum dan setelah diimplementasikan menggunakan HSRP. Pengujiannya menggunaktesan aplikasi packet tracer.

\section{Metode Pengambilan Data}

Pada Metode pengambilan data terkait dengan penelitian diantaranya dengan melakukan riset langsung ke PT. Indonesa Power, melakukan studi lietraut terkait dengan konsep HSRP serta melakukan wawancara dengan pihak terkait sistem pada PT.Indonesia Power.

\section{HASIL DAN PEMBAHASAN}

Hasil analisa yang didapat setelah melakukan riset pada jaringan komputer di PT.Indonesia Power adalah sebagai berikut Topologi jaringan yang sedang berjalan di PT Indonesia Power Jakarta menggunakan topologi jaringan Tree, Jaringan komputer ini digunakan untuk memenuhi kinerja karyawan dalam mengakses jaringan internet, jaringan local, pertukaran data, pengiriman e-mail, serta mencari informasi lain menggunakan web browser. Provider yang digunakan oleh PT Indonesia Power adalah ICON+ untuk jaringan WAN melalui Fiber Optic dan Link-Net untuk unit Jasa Pemeliharaan.

Kofigurasi ip address pada PT Indonesia Power yaitu 196.168.90.XXX kelas $\mathrm{C}$, default subnet mask kelas C 255.255.255.0/24 dengan protokol TCP/IP. Pemberian IP Address pada PT Indonesia Power Jakarta diberikan secara static dan dynamic, setiap client mendapatkan IP Address secara otomatis dari router, yaitu 192.168.90.XXX dengan subnet mask 255.255.255.0/24 dengan batas maksimal 20 user perlantai berikut skema jaringan 


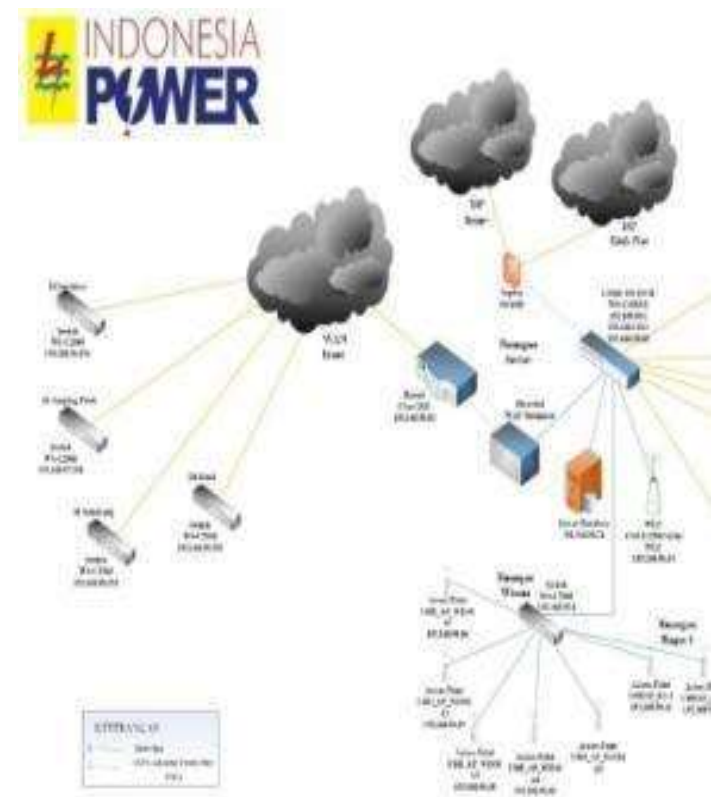

Sumber : PT.Indonesia Power Jakarta

Gambar 1. Skema Jaringan

Permasalahan jaringan yang terjadi di PT Indonesia Power Jakarta karena WAN Optimizer tidak berfungsi, maka alternatif pemecahan masalah dilakukan adalah dengan mengimplemtasikan Hot Standby Router Protocol (HSRP) dengan menambahkan 2 unit router catalist 2960 antara lain yaitu satu router active dan satu router standby. Router active yang dimaksud adalah router yang bertugas sebagai router utama pada jaringan komputer PT Indonesia Power Jakarta. Sedangkan router standby bertugas sebagai router backup apabila router active tidak berfungsi. Sehingga mampu mengantisipasi bila terjadinya Request Time Out (RTO) atau terputusnya jaringan serta meningkatkan kualitas jaringan komputer pada PT Indonesia Power Jakarta.

\section{Pembahasan}

Jaringan yang diusulkan pada PT Indonesia Power Jakarta dengan menggunakan Hot Standby Router Protocol (HSRP). Pada jaringan ini menggunakan dua router untuk menghilangkan kegagalan jaringan yang terjadi pada saat mengalami gangguan karena terputusnya koneksi dari jaringan WAN ke jaringan LAN. Adapun skema jaringan yang diusulkan adalah tetap menggunakan ISP dari Icon+, menggunakan satu buah router tambahan agar dapat menerapkan Hot Standby Router Protocol
(HSRP) sehingga dapat meningkatkan kualitas jaringan dan tetap menggunakan switch catalyst 4503 pada switch core. menambahkan 1 router catalyst 2960 pada jaringan PT Indonesia Power Jakarta. Hot Standby Router Protocol (HSRP) akan aktif jika router active mengalami ganguan atau device failure yang mengakibatkan terganggunya lalu lintas data. Pada saat router active mengalami gangguan router standby secara otomatis mengambil alih jalur lalu lintas data. Berikut gambar penambahan router pada PT.Indonesia Power, Jakarta. Penambahan router ditandai dengan kotak berwarna orange pada gambar 2 .

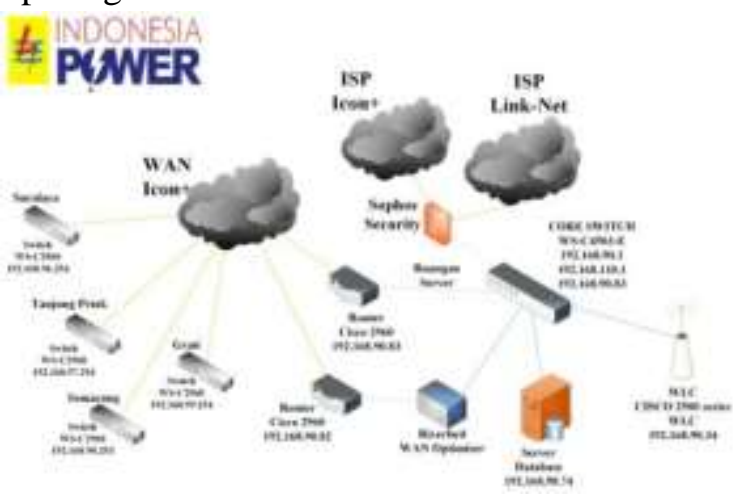

Sumber : Penelitian Pribadi

Gambar 2. Skema usulan

Berikut rancangan aplikasi untuk membuat Hot Standby Router Protocol (HSRP) yang disimulasikan dengan software cisco paket tracer: Pertama berikan IP Address pada router active, dan router standby seperti gambar dibawah ini.

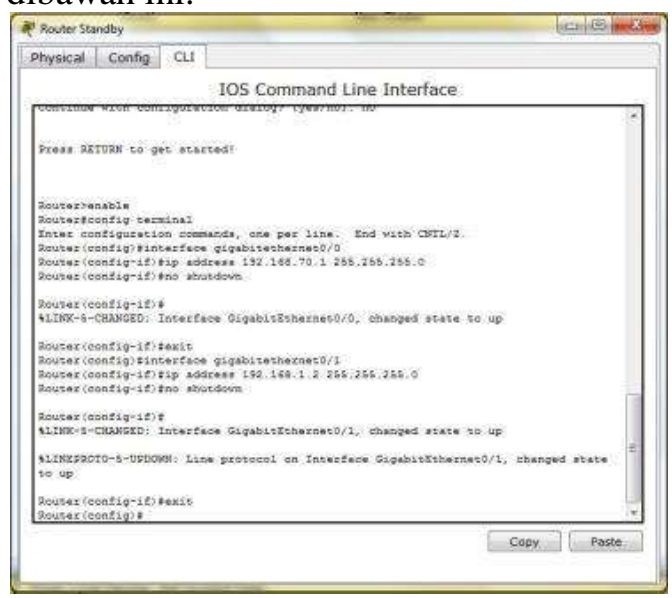

Sumber : Dokumentasi Pribadi

Gambar 3. Konfigurasi IP Address router

Selanjutnya setelah menambahkan IP Address

JIKA $\mid 131$ 
pada router active dan router standby. Lalu konfigurasi routing dynamic, yaitu routing eigrp dengan nomer AS 100.

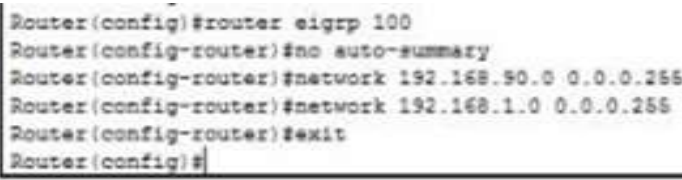

Sumber: Dokumentasi Pribadi.

Gambar 4. Konfigurasi EIGRP Router Active.

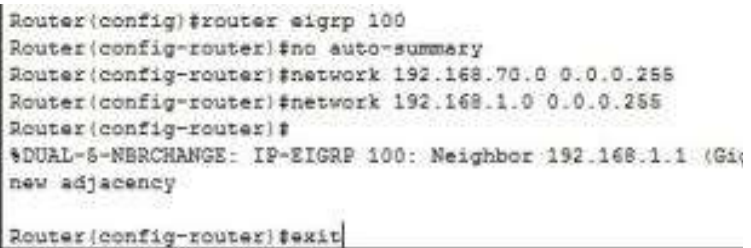

Sumber: Dokumentasi Pribadi.

Gambar 5. Konfigurasi EIGRP Router Standby

Setelah mengkonfigurasi EIGRP selanjutnya adalah mengkonfigurasi HSRP pada router active dan router standby, serta lakukan perintah "Show standby brief" pada router active dan router standby untuk melihat IP mana yang aktif dan standby seperti pada gambar dibawah ini.

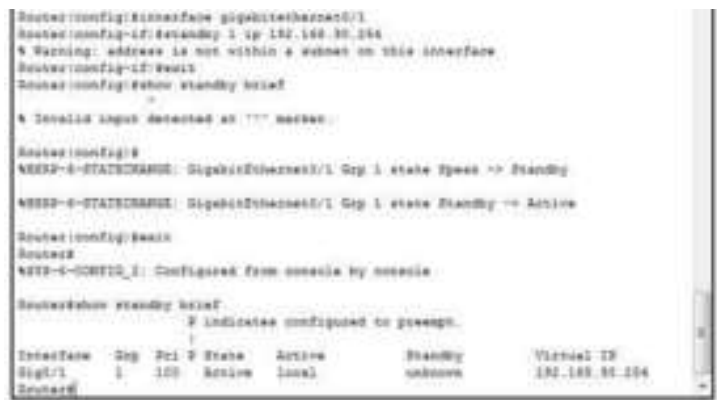

Sumber: Dokumentasi Pribadi.

Gambar 6. Konfigurasi HSRP Router Active.

Apabila ingin mengubah jalur priority nya ke router active maka input nilai priority menjadi lebih besar dari router standby. Kemudian lakukan pengecekan dengan memasukan perintah "show standby brief" Seperti dibawah ini.

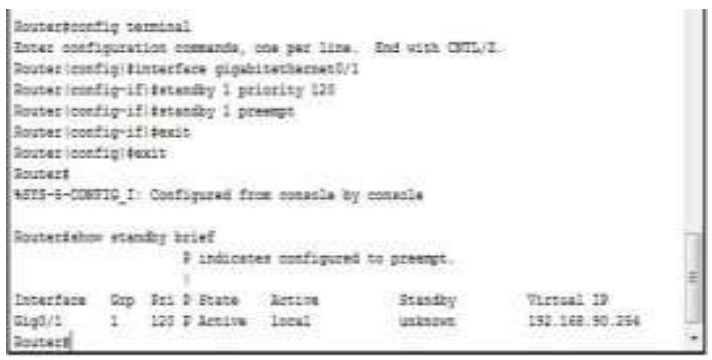

Sumber: Dokumentasi Pribadi.

Gambar 7. Konfigurasi Priority Router Active

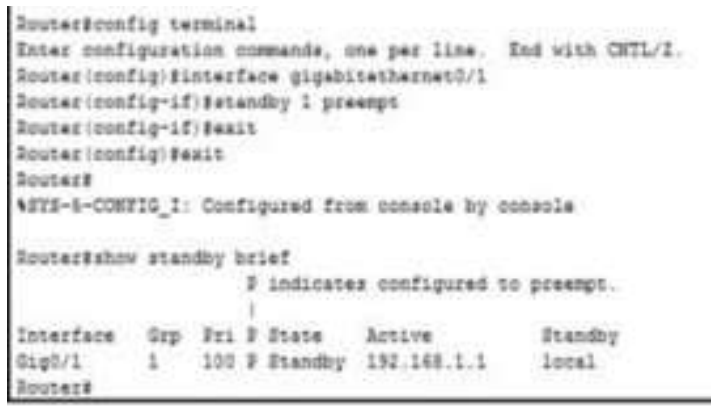

Sumber: Dokumentasi Pribadi.

Gambar 8. Konfigurasi Priority Router Standby

\section{Pengujian}

pengujian jaringan berdasarkan skema jaringan usulan dengan diterapkannya Hot Standby Router Protocol (HSRP) jaringan yang sebelumnya mengalami gangguan akan secara otomatis akan berpindah ke router standby. Sehingga dapat mengatasi masalah yang terjadi pada PT Indonesia Power Jakarta.

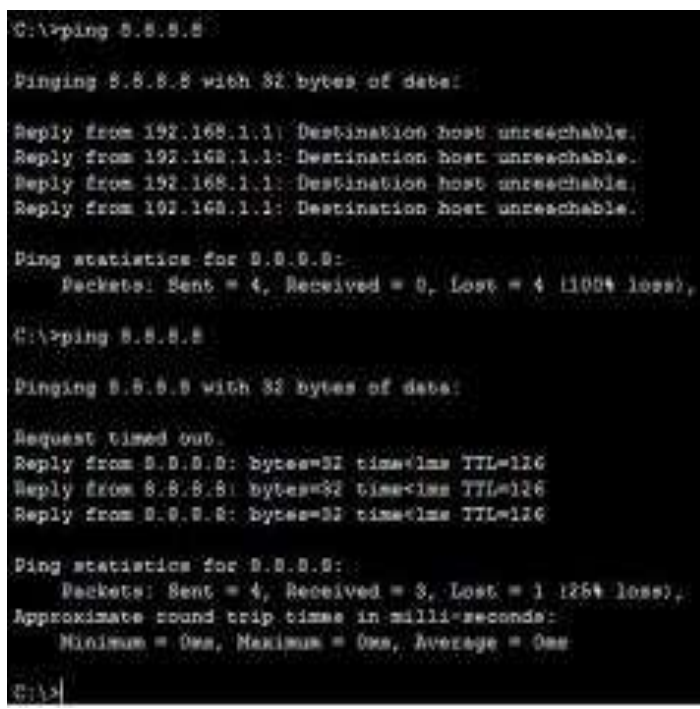

Sumber: Dokumentasi Pribadi.

Gambar 9. Pengujian Jaringan Akhir Setelah Diterapkannya HSRP. 


\section{KESIMPULAN}

Topologi di Indonesia Power Jakarta Pusat menggunakan topologi tree, Terdapat masalah pada router atau WAN optimizer, Implementasi Hot Standby Router Protocol (HSRP) berhasil diterapkan pada jaringan PT Indonesia Power Jakarta dan Penambahan beberapa perangkat mendukung berhasilnya implementasi Hot Standby Router Protocol (HSRP), didukung atas ditambahkannya perangkat pada router catalyst 2960, kabel Fiber Optik drop wire 2 core, kabel UTP Cat 6 TIA / EIA-568-B, konektor Fiber Optik FTTH SC, RJ45 Cat 6 Belden.

\section{REFERENSI}

Bhayangkara, Fiki Y \& Imam (2014) Implementasi Proxy Server dan Load Balancing Menggunakan Metode Per Connection Classifier (PCC) Berbasis Mikrotik. Yogyakarta: Jurnal Sarjana Teknik Informatika. Vol. 2, No. 2. ISSN: 2338-5197

Firmansyah, Moch.Wahyudi \&Rachmat AP. (2018). Analisis Perbandingan Kinerja Jaringan CISCO Virtual Router Redundancy Protocol (VRRP) dan CISCO Hot Standby Router Protocol (HSRP). Jakarta: Bagian Penerbitan STMIK Atma Luhur Pangkalpinang.

Hastanti, et.al (2015). Sistem Penjualan Berbasis WEB (E-Commerce) Pada Tata Distro Kabupaten Pacitan. Jurnal Bianglala Informatika. Vol. 3, No. 2. ISSN: 2338-8145

Hendrajati, Afredo dan Karis Widyatmoko. (2013). Rekayasa Perangkat Lunak Sentra Pelayanan Kepolisian Terpadu (SPKT) pada POLRESTABES Semarang. Semarang: Penerbitan Universitas Dian Nuswanto

Khadijah \& Yul H. (2016). Analisa Perbandingan Manajemen Jaringan Berbasis Mikrotik Dengan Cisco. Bireuen: Penerbitan Universitas Almuslim.

Nugroho, Kukuh. (2016). Jaringan Komputer Menggunakan Pendekatan Praktis. Kebumen. MEDIATERA.
Pamungkas, Wisnu H \& Eko P. (2018). Peracangan Jaringan Redundancy Link Menggunakan Konsep HSRP dan ETHERCHANNEL. Balikpapan. METIK Jurnal. Vol. 2, No. 1. ISSN: 2580-1503.

Purwanto, Wisnu \& Slamet R. (2018). Implementasi Metode HSRP pada Bank Jawa Barat dan Banten Kantor Wilayah I dan KCP Simpang Dago. Bandung. Jurnal Infotronik. Vol. 3, No. 1. ISSN: 2549-7758.

Rosmana \& Fitri Latifah. (2015). Implementasi Virtual Private Network (VPN) Dengan Otentikasi Radius Server pada PT. Anugrah Tunggal Mandiri. Jakarta: Jurnal Techno Nusa Mandiri. Vol. XII, No. 1. Retrieved from: www.repository.nusamandiri.ac.id

Wagiu, et. al. (2016). Evaluasi dan Perancangan Peningkatan Untuk Kerja Jaringan WiFi di Kampus UNSRAT. E-Journal Teknik Elektro dan Komputer. Vol. 5, No. 3. ISSN: 2301-8402.

Widodo, Adi. (2015). Implementasi Monitoring Jaringan Komputer Menggunakan Dude. Tangerang: Jurnal Teknologi Informasi. Vol. 11, No. 1. ISSN: 1979-1496

Yuisar, Liza Y\& Yanolanda S H. (2015). Analisa Pemanfaatan Proxy Server Sebagai Media Filtering Dan Caching Pada Jaringan Komputer. Bengkulu: Jurnal Media Infotama. Vol. 11, No 1, ISSN: 1858-2680 